DT 05/2010

\title{
Board Determinants in Banking Industry. An International Perspective
}

\author{
Pablo de Andrés Alonso \\ Universidad de Valladolid \\ pandres@eco.uva.es \\ Elena Romero Merino \\ Universidad Europea Miguel de Cervantes \\ meromero@uemc.es \\ Marcos Santamaría Mariscal \\ Universidad de Burgos \\ msanta@ubu.es \\ Eleuterio Vallelado González \\ Universidad de Valladolid \\ teyo@eco.uva.es
}

\begin{abstract}
We identify the factors influencing the board composition of an international sample of commercial banks over the period 1996-2006. After considering the dual role of the board as monitor and advisor, our analysis shows that no one board composition is optimal for the banking industry and that any such recommendation could harm bank governance. Our results suggest that more complex banks that have a low ownership concentration and are headquartered in a civil law country should have larger and more independent boards.
\end{abstract}

JEL Classification: G21; G34

Keywords: banks, board's determinants, board of directors, corporate governance 


\section{Board Determinants in Banking Industry. An International Perspective}

\section{Introduction}

The global financial crisis that began in 2008 brought into question the effectiveness of the governance mechanisms for the banking industry. Only nine years after the Enron scandal, the world once again became aware of the consequences of bad corporate governance. As the events of 2008 and beyond showed, when linked to the financial markets and, thus, financial intermediaries, the consequences of poor governance practices are even more harmful. Financial intermediaries are a cornerstone of the economy as they create financial assets, manage risks, and reduce the inherent information-asymmetry in monetary transferences among economic agents (Merton and Bodie, 2005). However, as the Basel Committee guidance on corporate governance for banking organizations (2010) points out, the existence of a governance problem can influence the behavior of these intermediaries. The resulting behavior may end in a bank failure, which can pose significant public costs and macroeconomic implications such as contagion risk and impact on payment risks. These macroeconomic implications, even at their less harmful level, are related to the loss of confidence of depositors, higher restrictions on credit access, and, consequently, a reduction in the investor process. Therefore, corporate governance of banks, defined as a set of mechanisms that ensure the efficient investment of financial resources, is a key issue in terms of maintaining economic stability. In line with these arguments, the board of directors, if optimally configured, can play a vital role in maintaining effective corporate governance.

The traditional literature on banking governance has addressed the effect of bank boards on corporate value. These studies suggest that board size, composition, and activity affect the 
board's effectiveness and, consequently, bank value. Contrary to the findings in nonfinancial studies, board size shows a positive (Adams and Mehram, 2008) or nonlineal (Andrés and Vallelado, 2008) effect on bank value. Regarding board independence, empirical evidence points at a positive effect of outsiders on bank value (Andrés and Vallelado, 2008) although its significance seems to be fairly poor (Adams and Mehram, 2008). Despite most banking literature showed different effects of board's composition on bank's performance compared to the nonfinancial firms, the codes of good governance were irrespectively used, and banks configured their boards according to the best practices principles of their nonfinancial counterparts.

Even more, following best practices guidelines without taking into consideration the idiosyncrasies of an entity (financial or nonfinancial) may not be an optimal decision. During recent years, research in banks has begun to follow the lead of nonfinancial studies (Boone et al., 2007; Coles et al., 2008; Lehn et al., 2009; Linck et al., 2008) to explain governance mechanisms as endogenously determined mechanisms. Thus, the question is no longer focused on the relation between governance systems and banking performance but rather on what determines those governance mechanisms (Adams and Mehram, 2008; Belkhir, 2009).

The most recent research on this issue uses explanations based on the optimal composition in terms of efficiency. To consider efficiency explanations, studies examine the two main functions of the board, advising and monitoring (Adams and Ferreira, 2007; Raheja, 2005), and investigate which firm specific features result in these two functions creating value (Guest, 2008). The need for advising is generally defined by bank size and complexity, and the need for monitoring is defined by the presence of a governance problem that is not solved by any other governance mechanism. 
Our paper sheds light on the board determinants of financial entities. We follow in the line of Adams and Mehram (2008) and Belkhir (2009), but we expand the industry knowledge base by using data from different countries. On the one hand, using an empirical analysis focused on companies belonging to the same industry, such as banking, has the advantage that most of the external control mechanisms have the same effect on all companies, at least of a certain size, in the industry (Belkhir, 2009). On the other hand, by studying several countries with different legal systems, we investigate whether the explanations for the board determinants are dissimilar depending on the parent company location.

We find that the codes of governance are so generally defined that they are of little help in coping with the governance problem of a particular bank. In fact, our results suggest that following the basic advice of the codes of good governance could result in increased costs as boards may become bigger and more independent than is necessary to fulfill the bank's advising and monitoring needs. In other words, we find that each bank must design its board taking into account its idiosyncrasies and the unique environment in which it operates its business.

The remainder of this paper proceeds as follows. In Section 2, we introduce our hypotheses on the determinants of boards in banking. Section 3 presents the data, variables, and econometric model. In Section 4, we provide the results, and in Section 5, we offer our conclusions.

\section{The Determinants of Boards in Banking}

The banking industry has particular idiosyncrasies that distinguish it from the nonfinancial sector (Prowse, 1997; Caprio and Levine, 2002). Banking entities are characterized by a high opacity, which relates to higher information asymmetries and to the complexity of bank business (Levine, 
2004). Second, the major providers of financial resources in the commercial banking industry are not shareholders but depositors. And finally, banks have a very high debt ratio, which exposes them to a major risk of insolvency in case of a bank run (Macey and O’Hara, 2003).

Also, boards of banking entities are quite different from boards of nonfinancial firms. In particular, boards in the banking sector tend to be bigger and more independent than in the nonfinancial sector. The mean size of a board in the banking sector ranges from 16 to 18 directors (Adams and Mehram, 2008; Andrés and Vallelado, 2008), which is higher than the average board size (11-13) reported for large nonfinancial firms (Andrés et al., 2005; Bhagat and Black, 2002; Coles et al., 2008; Lehn et al., 2009; Yermack, 2004). The mean proportion of outsiders on the board of a banking entity is between 70\% and 85\% (Adams and Mehram, 2008; Andrés and Vallelado, 2008; Belkhir, 2009), which is also higher than the average independence (60\%-70\%) of the boards in the nonfinancial sector (Andrés et al., 2005; Bhagat and Black, 2002; Coles et al., 2008; Lehn et al., 2009).

These differences between boards of financial and nonfinancial entities are also present in the remainder of the mechanisms of governance. The greater opacity in banking business makes controlling bank managers more difficult for bondholders, depositors, and shareholders (Levine, 2004). It also makes designing contracts that align the interests of managers and the rest of stakeholders more difficult and makes it easier for insiders to expropriate outside investors. Opacity also reduces the competitiveness of product market and takeover (Polo, 2007). In this scenario, regulation plays a special role as an additional governance mechanism. Although regulators' objectives may clash with those of other stakeholders, they are considered one of the main stakeholders in the banking industry (Diamond, 1984) because both the credit and payment systems and economic development depend on the bank's financial health. Regulation acts as an 
external governance force that monitors the functioning of bank boards through the laws of each country. So, boards are challenged to be configured to provide optimal advice and control while ensuring that their bank complies with the regulatory requirements in each of the countries in which they operate.

Previous research on board determinants explains a board's optimal configuration based on efficiency. Several studies show the influence of firm-specific internal and external characteristics on board composition (Boone et al., 2007; Guest, 2008; Lehn et al., 2009; Linck et al., 2008). These studies link the board's dual role as advisor and monitor to efficiency and, thus, value creation. In addition to specific firm characteristics, certain other issues must be considered when evaluating the power of the board to create value. First, the legal system of the country defines the type of governance problem (Beck et al., 2003; La Porta et al., 1998, 2000; Levine, 2005) and, consequently, the role of board (Adams and Mehran, 2008; Cook et al., 2004). Second, whenever several governance mechanisms coexist, their effects are endogenously determined according to the costs and benefits of each one in relation to the other (Adams and Mehram, 2008; Belkhir, 2009; Coles et al., 2008; Gillan et al., 2003; Linck et al., 2008). Consequently, the optimal corporate governance structure varies across firms depending on their specific characteristics, the legal system, and all other governance mechanisms. As such, the optimal size and independence of the banking board are related to the idiosyncrasies of the bank and its environment.

\subsection{BOARD'S ADVISORY ROLE}

The advisor role of the board consists of providing the CEO with expert counsel and access to information and resources and is more efficiently performed by a larger and more independent 
board that can provide important connections and greater information, knowledge, and expertise (Fama and Jensen, 1983; Guest, 2008). According to previous literature on nonfinancial firms, advisory needs are positively related to firm’s size (Baker and Gompers, 2003; Coles et al., 2008; Denis and Sarin, 1999; Fahlenbrach, 2009, Guest, 2008; Iwasaki, 2008; Kim et al., 2007; Lehn et al., 2009; Linck et al., 2008) and complexity; the latter is generally measured by activity diversification (Denis and Sarin, 1999; Coles et al., 2008; Iwasaki, 2008; Linck et al., 2008), firm leverage (Denis and Sarin, 1999; Coles et al., 2008; Iwasaki, 2008; Linck et al., 2008), and age (Boone et al., 2007; Coles et al., 2008; Fahlenbrach, 2009; Guest, 2008; Linck et al., 2008). In the banking industry, boards also serve a key advisory role to managers regarding strategy identification and implementation (Andrés and Vallelado, 2008). This role is even more critical in the banking industry due to the high complexity of financial business. So, the advisory role of banking boards should be highly positively related to the entity's size and complexity. Thus, we hypothesize:

H1: Larger and more complex banks may benefit from an advisory board, which will result in larger and more independent boards

\subsection{BOARD’S MONITORING ROLE}

The monitoring role of the board consists of controlling the managerial behavior to avoid the investors' wealth expropriation (Fama and Jensen, 1983). A board's monitoring role is more efficiently performed by larger and more independent boards (Guest, 2008; Lehn et al., 2009; Raheja, 2005). This relation is particularly relevant in industries such as commercial banking, in which the benefits from a larger board—such as political influence with a regulatory body or 
assistance in attracting more business (Agrawal and Knoeber, 2001; Gillan et al., 2003)—can outweigh coordination and free rider problems (Jensen, 1993; Yermack, 1996).

The banks' need of an effective monitoring board is related to the existence of alternative governance mechanisms. In addition to the board of directors, the legal and institutional environment, and the ownership structure can also serve as monitoring mechanisms to reduce agency conflicts and ease the governance problem between investors and managers (Li, 1994; Bathala and Rao, 1995; Mak and Li, 2001). Thus, when a substitute governance mechanism provides effective monitoring, the board does not need to increase its size by including more outsiders to enhance its monitoring role.

Regarding the legal and institutional environment, literature on corporate governance illustrates that protection of investors' rights vary significantly among countries, due in part to differences in legal origin. Whereas civil law countries tend to provide investors with weaker legal rights, common law countries extend stronger legal protection to shareholders and investors (La Porta et al., 1998). So those banks located in civil law countries (i.e., weaker legal protections) cope with a potential problem of investors' expropriation by using substitute mechanisms of corporate governance such as the board. As a consequence, legal systems will be highly correlated with board design (Gillette et al., 2008). Therefore, we hypothesize:

H2: Banks whose parent company is located in countries with weak shareholder protection may benefit from boards with a stronger monitoring role, which will result in larger and more independent boards. 
Ownership concentration is also understood as a governance mechanism that can substitute for a board's monitoring role and define a board's composition. When a blockholder is present with the firm, the board is generally composed of fewer directors to diminish decisionmaking costs (Kieschnick and Moussawi, 2004). However, with regard to the percentage of outsiders, previous evidence is not conclusive. On the one hand, in nonfinancial firms, blockholders often improve the board and encourage its advisory role by supporting the inclusion of outsiders on the boards (Bathala and Rao, 1995; Kieschnick and Moussawi, 2004), especially when the blockholder is an institutional investor (Nielsen, 2008). On the other hand, the scarce literature on banking boards shows that blockholders substitute the board monitoring role by reducing not only the number of directors but also the percentage of outsiders (Belkhir, 2009). Following these arguments, we hypothesize:

H3: Banks with concentrated ownership do not require a monitoring board, and, thus, they may benefit from a smaller and less independent board.

In addition to the substitution effects of alternative governance mechanisms, the configuration of a monitoring board depends on the monitoring costs. When monitoring costs increase, boards will reduce their monitoring role, which leads to a reduction of their size and independence (Raheja, 2005). Thus, monitoring costs, which increase with the entity's risk and growth, have a negative impact on the size of the board (Boone et al., 2007; Guest, 2008; Linck et al., 2008) and on outsider proportion (Boone et al., 2007; Guest, 2008; Kim et al., 2007; Linck et al., 2008). No specific literature exists on monitoring costs in banks; however, our previous arguments are appropriate for the banking industry. As a result, we hypothesize: 
H4: Banks with higher growth opportunities or risks have higher monitoring costs, which results in smaller and less independent boards.

\section{Research Method}

We examine our hypotheses for a sample of 73 listed commercial banks from seven OECD countries during the period from 1996 to 2006 comprising 651 bank-year observations. This unbalanced panel of data represents $32.2 \%$ of the total number of banks but about $80 \%$ of banking assets and equity of the seven countries.

Board data to build the panel are mainly obtained from Spencer\&Stuart database. We obtain complementary information on boards from banks' web sites. Additionally, we use the Compustat database to obtain financial statements of banks from 1996 to 2006. Finally, we use Bankscope and Thomson One Banker to obtain full data about ownership structure.

The panel data includes banks from three common law countries (Canada, the United Kingdom, and the United States) and four from civil law countries (France, Italy, Netherlands, and Spain). All of these countries are developed nations with well-functioning legal and institutional environments. All of the banks have a one-tier board structure, except the French system, which offers corporations the choice of one- or two-tier boards. Our sample includes only the banks that opt for one tier (89\% of the French banks opt for one-tier banks).

\subsection{VARIABLES AND STATISTICS}

Table 1 presents a general description of our sample and variables. We measure board size and independence as the number of total directors (BOARD SIZE) and the percentage of outsiders 
(BOARD OUTSIDERS), respectively. According to our data, boards of banking entities are composed, on average, of 16 directors who are mostly outsiders (80\%). These figures coincides with those presented in Andrés and Vallelado (2008) for a similar sample; and they are in line with other North American studies that find average board size between 14 (Belkhir, 2009) and 18 (Adams and Mehram, 2008) and independence between 70\% (Adams and Mehram, 2008) and 80\% (Belkhir, 2009).

\section{[INSERT TABLE 1 ABOUT HERE]}

We define the size and complexity of bank activity with three variables related to the bank's volume of assets (ASSETS), age (AGE), liabilities-to-total assets ratio (LEVERAGE), and, diversification of activities (DIVERSIFICATION). The diversification is measured in terms of deposits and loans following Pathan and Scully (2010) and Stiroh and Rumble (2006). The banks in our sample handle an average of volume of assets of US\$192 billion, and their leverage is above $93 \%$ (including deposits as debt).

We use a dummy variable to identify the legal tradition of the country in which the bank's parent company is located (CIVIL), and we measure ownership concentration as the percentage of equity in hands of the major shareholder (OWNERSHIP). According to our data, a major shareholder owns close to $13 \%$ of the bank equity. We also include two variables that are related to monitoring costs of the board: the bank's growth opportunities, proxied by the firm's market-to-book value ratio (Q), and its risk (RISK), measured by Z-score ratio (Laeven and Levine, 2009; Beck et al. 2010). We observe that, on average, market value is about three times the book value of banks and the mean of the risk (higher z-score indicates lower risk) is above 5. 
Finally, we incorporate three control variables concerning return on equity (ROE), the bank's merger activity (MERGER), and the publish date of a code of good governance in the country in which the bank's parent company is located (CODE). According to our data, the mean of the return on equity is about $15 \%$, and throughout the years of our study, $14 \%$ of the banks underwent a merger. In addition, every country of our sample published at least one code of good governance between 1996 and 2006: four in the United States, three in France; two in Canada, England, and Spain; and one in Italy and the Netherlands.

\subsection{ECONOMETRIC MODEL}

Our sample includes time series (1996-2006) and cross-sectional data from 73 banks. Panel data analysis is the most efficient tool to analyze this kind of sample because it allows us to consider the unobservable and constant heterogeneity of each bank (e.g., the management quality and style, market perception, business strategy). Also, as our dependent variable may be simultaneously determined with some of the independent variables (e.g., market-to-book ratio, volume of assets, etc.), we need to use an econometric method that can deal with endogeneity as well as with the unobservable fixed effects of each commercial bank. We overcome this econometric challenge by using a general method of moments (GMM), which allows us to build instruments for those variables that are potentially endogenous.

Thus, we use the two-step system estimator (SE) with adjusted standard errors for potential heteroskedasticity proposed by Arellano and Bover (1995) and Blundell and Bond (1998). This econometric method considers the unobserved effect that transforms the variables into first differences and uses GMM to deal with endogeneity problems. Those differences are reflected in the quality of the instruments involved (Levine et al., 2000). Specifically, the lagged 
values (in our case, the dependent variables) frequently involve weak instruments for the prediction of changes in the board size and independence. The existence of weak instruments can lead to poor asymptotic precision in finite samples (Alonso-Borrego and Arellano, 1999). Therefore, in our econometric models, we use an estimator that lessens this problem, substituting the specification in differences with the original regression specified in levels similar to the system estimator (Blundell and Bond, 1998; Huang and Ritter, 2009; Öztekin and Flannery, 2009). Performing the model in that way, the system estimator involves two kinds of equations, each containing their own instruments. The first category of equations is in levels and its instruments are the lagged differences in the dependent variable and the independent variables. The second category of equations consists of equations in first differences and uses the levels of the dependent variable and the independent variables as instruments (Arellano and Bond, 1998; Goergen and Renneboog, 2001; Wooldrigde, 2002). For our case, using the GMM method, we build instruments for those variables that are potentially endogenous.

To test the validity of our model specifications, we calculate the Hansen test of overidentification of restrictions. This test examines the lack of correlation between the instruments and the error term. The AR1 and AR2 statistics measure first- and second-order serial correlation. Given the use of first-difference transformations, we expect some degree of first-order serial correlation, although this correlation does not invalidate our results. However, the presence of second-order serial correlation does signal omitted variables. We also compute the Wald test of joint significance for all independent variables. In addition, we use the adjustment for small samples suggested by Windmeijer (2005). Because our sample size is not very large, the Windmeijer proposal improves the robustness of our results and avoids any potential downward bias in the estimated asymptotic standard errors. 
We develop two empirical models to evaluate board composition: one for explaining board size and the other for explaining board independence. The independent variables are bank size (ASSETS), age of the bank (AGE), percentage of liabilities (LEVERAGE), the bank's activity diversification (DIVERSIFICATION), the country's legal tradition (CIVIL), ownership concentration (OWNERSHIP), market-to-book ratio (Q), bank risk (RISK), and three control variables (ROE, MERGER, and CODE). Analytically, the regression Model (1) with the board size is

$$
\begin{aligned}
\text { BOARD SIZE }_{i, t}= & \beta_{0}+\beta_{1} \text { ASSETS }_{i, t}+\beta_{2} \text { AGE }_{i, t}+\beta_{3} \text { LEVERAGE }_{i, t}+ \\
& \beta_{4} \text { DIVERSIFICATION }_{i, t}+\beta_{5} \text { CIVIL }_{i, t}+\beta_{6} \text { OWNERSHIP }_{i, t}+ \\
& \beta_{7} Q_{i, t}+\beta_{8} \text { RISK }_{i, t}+\beta_{9} \text { ROE }_{i, t}+\beta_{10} \text { MERGER }_{i, t}+ \\
& \beta_{11} \text { CODE }_{i, t}+\beta_{12} \text { YEAR }_{i, t}+d_{t}+\eta_{i}+v_{i, t}
\end{aligned}
$$

The regression Model (2) with the board independence is

$$
\begin{aligned}
\text { BOARD OUTSIDERS }_{i, t}= & \beta_{0}+\beta_{1} \text { ASSETS }_{i, t}+\beta_{2} \text { AGE }_{i, t}+\beta_{3} \text { LEVERAGE }_{i, t}+ \\
& \beta_{4} \text { DIVERSIFICATION }_{i, t}+\beta_{5} \text { CIVIL }_{i, t}+\beta_{6} \text { OWNERSHIP }_{i, t}+ \\
& \beta_{7} Q_{i, t}+\beta_{8} \text { RISK }_{i, t}+\beta_{9} \text { ROE }_{i, t}+\beta_{10} \text { MERGER }_{i, t}+ \\
& \beta_{11} \text { CODE }_{i, t}+\beta_{12} \text { YEAR }_{i, t}+d_{t}+\eta_{i}+v_{i, t}
\end{aligned}
$$

\section{Empirical Results}

Table 2 provides the estimations of the Models (1) and (2). As we expected, banks' advisory needs are directly related to their scope of operations-but only when they are proxied by the banks' size. As Table 2 shows, as the bank increases in size (ASSETS), the board size and independence also increases. These results are in line with those obtained by previous authors for different samples (i.e., Baker and Gompers, 2003; Boone et al., 2007; Coles et al., 2008; Denis 
and Sarin, 1999; Guest, 2008; Lehn et al., 2009; Linck et al., 2008). These finding corroborate the notion that banks with higher asset volume require a board that can support the CEO in his or her decision making. These boards, therefore, increase the number of members-especially outside members - of their boards to provide more information and expertise in guiding and defining the bank's future strategies. The scarce literature on financial entities also shows this effect (Adams and Mehram, 2008; Belkhir, 2009; Pathan and Scully, 2010). Conversely, none of the other variables related to the bank's complexity (AGE, LEVERAGE, and DIVERSIFICATION) show a significant effect on the boards’ size or independence.

\section{[INSERT TABLE 2 ABOUT HERE]}

Regarding the monitoring role of the board, we analyze both the monitoring costs linked to the bank's growth and risk and the substitution effect of an alternative supervising mechanism. The influence of the monitoring costs (Q) in the board composition is significant only when we are referring to the board's independence. Following the results obtained by Denis and Sarin (1999), Lehn et al. (2009), and Linck et al. (2008), among others, we observe that higher monitoring costs, related to the entity’s higher growth options, results in a less independent board to reduce the functioning costs of their governance mechanism and to speed up their decision making process.

With regard to the substitution effect, we find that those banks whose parent company is located in a country with low legal protection of shareholders' rights (CIVIL) need the board to safeguard shareholders' interest, at least in terms of the board's independence. Our results also suggest that ownership concentration (OWNERSHIP) is negatively related to the bank's need for 
the board to undertake a monitoring role, although, at least in the basic models, these effects are not significant. These outcomes, however, are not new in literature as prior studies have found the sign of the effect of ownership structure on board composition and conclusive empirical evidence elusive at best.

Two control variables, MERGER and CODE, have an important influence on the board size and independence. Whenever the bank goes through a merger process, the number of board members increases but mainly by maintaining the insiders of the companies that are being joined together. In addition, when a code of good governance is published, bank boards attempt to adjust their board composition to the code recommendations; following the last round of good governance codes, boards moved to considerably reduce their size and increase their independence. Thus, contrary Karolyi (2006), who found that that boards change in anticipation of the codes, we find that board change as a result of them.

We expand our analysis by using interacted variables to identify the non linear effect of the ownership concentration and the predominant effect when two different governance mechanisms collide.

Some previous authors have identified a nonlinear relation between ownership concentration and board composition (e.g., Gugler and Yurtoglu, 2003; Lefort and Urzúa, 2008). As shown in Table 3, when we include the quadratic specifications (SQUARED OWNERSHIP), our results evidence a nonlinear relation between ownership concentration and board size. The coefficient of the linear term for board size (OWNERSHIP) shows a significant and negative sign whereas the coefficient on the quadratic term (SQUARED OWNERSHIP) is positive and significant at the 5\% confidence level. This result supports the notion that although the ownership monitoring role increases as more shares are accumulated by the main shareholder, at 
a certain level of ownership concentration, the potential expropriation on other stakeholders, especially depositors, may outweigh the benefits of the large shareholder. Therefore, when ownership concentration is excessively high, the board can avoid potential expropriation by adding more members to monitor both the managerial team and the main shareholder.

\section{[INSERT TABLE 3 ABOUT HERE]}

Regarding the interactive effect between governance mechanism, we include the variables CIVIL*OWNERSHIP and MERGER*OWNERSHIP. Our results, shown in Table 3, maintain the same signs of the basic models, although some of the variables lose their significance as the new variables we include absorb most of the explicative power of the model. So we find that board size is negatively related to ownership concentration (OWNERSHIP), which supports the arguments of the substitution effect of alternative governance mechanisms. Also, the coefficients of the interactive variables are significant and require a distinct explanation.

\section{[TABLE 4 ABOUT HERE]}

On the one hand, the coefficient of the interactive variable CIVIL*OWNERSHIP refers to the incremental effect of ownership concentration on those banks whose parent company is located in a country with a civil legal tradition compared to the reference group of banks whose parent company is located in a country with a common legal tradition. Our results show that the effect of the ownership concentration on the board size is negative and this effect is stronger in 
the common law countries (the OWNERSHIP coefficient is -0.380) than in the civil law ones (the coefficient of OWNERSHIP in civil law tradition is $-0.380+0.331=-0.049$ ). The t1 test (4.47) allow us reject the null hypothesis that the sum of the coefficients of the interactive variable (CIVIL*OWNERSHIP) and the non-interactive one (OWNERSHIP) is zero. This result evidences the fact that the ownership concentration serves as a substitute governance mechanism for the board of directors in monitoring but this mechanism is more important in common law countries than in civil law ones.

This result is not surprising but it complements our findings for the variable SQUARED OWNERSHIP. As we previously described, at the lower levels of ownership concentration it can act as a substitute monitoring mechanism for the board, but we have also observed that this effect turns into its opposite at the higher levels of ownership concentration. So, the substitution effect between board and ownership concentration is especially evidenced in common law countries where the level of ownership concentration is lower- and it loses part of its significance in civil law countries where the levels of ownership concentration are generally higher.

On the other hand, the coefficient of the MERGER*OWNERSHIP variable corresponds to the incremental effect of ownership concentration on those banks that goes through a merger compared to the reference group of nonmerged banks. According to our results, for those banks that undergo a merger process, the link between ownership concentration and board size is positive (the OWNERSHIP coefficient for these banks is $0.048(-0.074+0.122)$ and its t2 test (6.18) allow us reject the null hypothesis that the sum of the coefficients of the interactive variable (MERGER*OWNERSHIP) and the non-interactive one (OWNERSHIP) is zero). Thus, even though the present of a blockholder decreases the need for a large monitoring board (the coefficient of OWNERSHIP variable is -0.074), when two banks with large blockholders merge, 
the number of board members will increase. In other words, the effect of the merger, which increases the size of the board, prevails over the substitution effect of the ownership concentration, which decreases the size of the board.

\section{Conclusions}

As Cooke (2002) suggested, when investors scour the globe for potentially lucrative investments they also look for transparency and disclosure of financial information, and nations lacking good corporate governance practices are less likely to attract foreign investment. Among good corporate practices, an optimal board composition to both monitor and advise the managerial team is a signal of reliance for potential investors. However, the optimal composition of a board remains an open question.

Although considerable research has addressed the influence of the board composition on the firm's and bank's performance, which has been used as a base for the recommendations included in the codes of good practices, none of these results have proven absolutely conclusive. The most recent research on board composition suggests that a single optimal structure cannot be made to fit every organization: Each entity, depending on its characteristics and environment, may need a different board.

In line with these arguments, we reanalyze the board composition of banks. We use an international sample of financial entities to explore how the composition of the board of directors is related to the entity's characteristics and its legal framework. Our results corroborate that board composition is endogenously determined. Specifically, we find that board size and independence are higher when the advisory or monitoring needs of the bank increases. We find support for the advisory dimension of the board when looking at the board composition of the 
bigger banks. Also, we show that a substitution effect of alternative governance mechanisms (concentrated ownership, merger, legal protection of shareholders' rights, and board of directors) exists, especially when we study the effect of ownership concentration by including quadratic specifications or interacted variables. Finally, we find support for a negative effect of the monitoring costs on the boards' independence.

All these results suggest the impossibility of defining a model of optimal board for every banking entity. If we consider the firm and country characteristics to design an efficient board for an entity, we obtain a different model of board for each firm. In this line of arguments, our study shows the potential dangers derived from the direct application of the recommendations included in the codes of good practices without considering the specific characteristics of the entity and the environment in which it operates. However, as we observe from our data, despite what may serve their best interests, banks adapt their boards' composition to new codes of governance by reducing the number of insiders that compose the board without taking into account the entity's idiosyncrasies.

We draw two main conclusions from this study. First, previous literature about the relation between board composition and firm/bank performance needs to be reappraised. The nonconclusive results regarding the effect of board's effectiveness on bank value can be derived from the endogenously structured board of directors. Second, public recommendations about governance need to be reexamined. How can a code of governance that is defined in generic terms be effectively applied when each entity has a unique definition of an optimal board? In light of our results, applying the codes of good governance with no consideration of the characteristics of the entity or its environment does not seem advisable. For example, the costs of increasing the independent of a board could greatly exceed its benefits when the entity's 
monitoring or advising needs are reduced. Also, advocates of small boards may be undervaluing the informational advantage derived from adding more directors, especially if the entity is quite large and complex but easy to monitor.

Our findings suggest several possible avenues for future research. For instance, the analysis of the importance of a board's ability to adapt for bank survival is of particular interest during a period of economic recession. To survive, many banking entities are undergoing a merger process or seeking public financial funding to obtain liquidity. Banks that survive could be compared to those banks that become extinct (via bankruptcy or takeover) or that have received public funds. If the comparison does not produce analogous results, we may infer that boards' adaptation is necessary to survive in competitive markets. Also, as previously argued, the literature about corporate governance in financial entities needs to be reappraised to give entrance not only to the endogeneity problem in board composition but also to the dual role of the board both as advisor and monitor for the managerial team. 


\section{References}

Adams, R.B. and Ferreira, D. (2007) A theory of friendly boards, Journal of Finance 62, 217250.

Adams, R.B. and Mehran, R. (2008) Corporate performance, board structure, and their determinants in the banking industry, FRB of New York Staff Report no. 330.

Agrawal, A. and Knoeber, C.R. (2001) Do Some Outside Directors Play a Political Role?, Journal of Law and Economics 44, 179-198.

Alonso-Borrego, C. and Arellano, M. (1999) Symmetrically normalized instrumental variable estimation using panel data, Journal of Business and Economic Statistics 17, 36-49.

Andrés, P., Azofra, V. and Lopez, F.J. (2005) Corporate boards in OECD countries: size, composition, compensation, functioning and effectiveness, Corporate Governance: An International Review 13, 197-210.

Andrés, P. and Vallelado, E. (2008) Corporate governance in banking: the role of the board of directors, Journal of Banking and Finance 32, 2570-2580.

Arellano, M. and Bond, S. (1998) Dynamic panel data estimation using DPD98 for Gauss, Unpublished manuscript, Center for Monetary and Financial Studies, Madrid.

Arellano, M. and Bover, O. (1995) Another look at the instrumental variables estimation of error components models, Journal of Econometrics 68, 29-51.

Baker, M. and Gompers, P. (2003) The determinants of board structure at the initial public offering, Journal of Law and Economics 46, 569-598.

Bathala, C. and Rao, R.P. (1995) The determinants of board composition: an agency theory perspective, Managerial and Decision Economics 16, 59-69. 
Beck, T., Demirgüç-Kunt, A. and Levine, R. (2003) Law, endowments, and finance. Journal of Financial Economics 70, 137-181.

Beck, T., Demirgüç-Kunt, A. and Levine, R. (2010) Financial institutions and markets across countries and over time: the updated financial development and structure database, World Bank Economic Review 24, 77-92.

Belkhir, M. (2009) Board of directors' size and performance in the banking industry, International Journal of Managerial Finance 5, 201-221.

Bhagat, S. and Black, B. (2002) The non-correlation between board independence and long-term firm performance, Journal of Corporation Law 27, 231-274.

Blundell, R. and Bond, S. (1998) Initial conditions and moment restrictions in dynamic panel data models, Journal of Econometrics 87, 115-143.

Boone, A.L., Field, L.C., Karpoff, J.M. and Raheja, C.G. (2007) The determinants of corporate board size and composition: an empirical analysis, Journal of Financial Economics 85, 66-101.

Caprio, G. and Levine, R., (2002) Corporate governance in finance: concepts and international observations, in: R.E. Litan, M. Pomerleano, V. Sundararajan (eds.), Financial Sector Governance: The Roles of the Public and Private Sectors. Brookings Institution Press, Washington, DC, pp. 17-50.

Coles, J.L., Daniel, N.D. and Naveen, L. (2008) Boards: does one size fit all? Journal of Financial Economics 87, 329-356.

Cook, D., Hogan, A. and Kieschnick, R. (2004) A study of the corporate governance of thrifts, Journal of Banking and Finance 28, 1247-1271. 
Cooke, D.C. (2002) The governance of asset management companies: selected observations, in: R.E. Litan, M. Pomerleano, V. Sundararajan (eds.), Financial Sector Governance: The Roles of the Public and Private Sectors. Brookings Institution Press, Washington, DC, pp. 209-233.

Denis, D.K. and Sarin, A. (1999) Ownership and board structure in publicly traded corporations, Journal of Financial Economics 52, 187-223.

Diamond, D. (1984) Financial intermediation and delegated monitoring, Review of Economic Studies 51, 393-414.

Fahlenbrach, R. (2009) Shareholder rights, boards, and CEO compensation, Review of Finance $13,81-113$

Fama, E. and Jensen, M.C. (1983) Separation of ownership and control, Journal of Law and Economics 26, 301-325.

Gillan, S.L., Hartzell, J.C. and Starks, L.T. (2003) Explaining corporate governance: boards, bylaws, and charter provisions, unpublished paper, Weinberg Center for Corporate Governance Working Paper no. 2003-03.

Gillette, A.B., Noe, T.H. and Rebello, M.J. (2008) Board structures around the world: an experimental investigation, Review of Finance 12, 93-140.

Goergen, M., and Renneboog, L. (2001) Investment policy, internal financing and ownership concentration in the UK, Journal of Corporate Finance 7, 257-284.

Gugler, K. and Yurtoglu, B.B. (2003) Corporate governance and dividend pay-out policy in Germany, European Economic Review 47, 731-758.

Guest. P.M. (2008) The determinants of board size and composition: Evidence from the UK, Journal of Corporate Finance 14, 51-72. 
Huang, R. and Ritter, J. (2009) Testing theories of capital structure and estimating the speed of adjustment, Journal of Financial and Quantitative Analysis 44, 237-271.

Iwasaki, I. (2008) The determinants of board composition in a transforming economy: evidence from Russia, Journal of Corporate Finance 14(5), 532-549.

Jensen, M. (1993) The modern industrial revolution, exit, and the failure of internal control systems, Journal of Finance 48, 831-880.

Karolyi, G.A. (2006) The world of cross-listings and cross-listings of the world: challenging conventional wisdom, Review of Finance 10, 99-152.

Kieschnick, R. and Moussawi, R. (2004) The board of directors: A bargaining perspective, unpublished working paper, University of Texas at Dallas.

Kim, K.A., Kitsabunnarat, P. and Nofsinger J.R. (2007) Large shareholders, board independence, and minority shareholder rights: evidence from Europe, Journal of Corporate Finance 13, 859-880.

La Porta, R., Lopez de Silanes, F., Shleifer, A. and Vishny, R.W. (1998) Law and finance, Journal of Political Economy 106, 1113-1155.

La Porta, R., López de Silanes, F., Shleifer, A. and Vishny, R.W. (2000) Investor protection and corporate governance, Journal of Financial Economics 58, 3-27.

Laeven, L. and Levine, R. (2009) Bank governance, regulation and risk taking, Journal of Financial Economics 93, 259-275.

Lefort, F. and Urzúa, F. (2008) Board independence, firm performance and ownership concentration: evidence from Chile, Journal of Business Research 61, 615-622.

Lehn, K., Patro, S. and Zhao, M. (2009) Determinants of the size and structure of corporate boards: 1935-2000, Financial Management 38, 747-780. 
Levine, R. (2004) The corporate governance of banks: A concise discussion of concepts and evidence, unpublished paper, World Bank Policy Research working paper no. 3404. Available at http://ssrn.com/abstract=625281, accessed September 20, 2010.

Levine, R. (2005) Law, Endowments, and Property Rights, Journal of Economic Perspectives 19, $61-88$.

Levine, R., Loayza, N. and Beck, T. (2000) Financial intermediation and growth: causality and causes, Journal of Monetary Economics 46, 31-77.

Li, J. (1994) Ownership structure and board composition: a multi-country test of agency theory predictions, Managerial and Decision Economics 15, 359-368.

Linck, J., Netter, J. and Yang, T. (2008) The determinants of board structure, Journal of Financial Economics 87, 308-328.

Macey, J. and O’Hara, M. (2003) The corporate governance of banks, FRBNY Economic Policy Review, April, 91-107.

Mak, Y.T. and Li, Y. (2001) Determinants of corporate ownership and board structure: evidence from Singapore, Journal of Corporate Finance 7, 235-256.

Merton, R.C. and Bodie, Z. (2005) Design of financial systems: towards a synthesis of function and structure, Journal of Investment Management 3, 1-23.

Nielsen, K.M. (2008) Institutional investors and private equity, Review of Finance 12, 185-219.

Öztekin, Ö. and Flannery, M.J. (2009) Institutional Determinants of Capital Structure Adjustment Speeds, unpublished working paper, University of Kansas, University of Florida. Available at http://ssrn.com/abstract=1364273, accessed September 20, 2010.

Pathan, S. and Skully, M. (2010) Endogenously structured boards of directors in banks, Journal of Banking and Finance 34, 1590-1606. 
Polo, A. (2007) Corporate governance of banks: the current state of the debate, unpublished working paper, MPRA paper no. 2325. Available at http://mpra.ub.unimuenchen.de/2325/1/MPRA_paper_2325.pdf, accessed September 20, 2010.

Prowse, S. (1997) The corporate governance system in banking: what do we know? BNL Quarterly Review, Special Issue, March, 11-40.

Raheja, C.G. (2005) Determinants of board size and composition: A theory of corporate boards, Journal of Financial and Quantitative Analysis 40, 283-306.

Stiroh, K.J. and Rumble, A. (2006) The dark side of diversification: the case of US financial holding companies, Journal of Banking and Finance 30, 2131-2161.

Windmeijer, F. (2005) A finite sample correction for the variance of linear two-step GMM estimators, Journal of Econometrics 126, 25-51.

Wooldrigde, J. (2002) Econometric analysis of cross section and panel data, MIT Press, London.

Yermack, D. (1996) Higher market valuation of companies with small board of directors, Journal of Financial Economics 40, 185-211.

Yermack, D. (2004) Remuneration, retention, and reputation incentives for outside directors, Journal of Finance 59, 2281-2308. 
Table 1. Hypotheses, variables and statistics

\begin{tabular}{|c|c|c|c|c|c|c|c|c|}
\hline & \multirow[b]{2}{*}{ Definition } & \multirow[b]{2}{*}{ Variable } & \multicolumn{2}{|c|}{ Predictions } & \multirow[b]{2}{*}{ Mean } & \multirow[b]{2}{*}{ Std. Dev. } & \multirow[b]{2}{*}{ Min. } & \multirow[b]{2}{*}{ Max. } \\
\hline & & & Size & $\overline{\text { Independence }}$ & & & & \\
\hline \multicolumn{9}{|l|}{ Dependent variables } \\
\hline Board size & Total number of directors & BOARD SIZE & - & - & 15.690 & 4.412 & 6.000 & 32.000 \\
\hline Board independence & Percentage of board seats held by outsiders & $\begin{array}{l}\% \text { BOARD } \\
\text { OUTSIDERS }\end{array}$ & - & - & 0.797 & 0.149 & 0.000 & 1.000 \\
\hline \multicolumn{9}{|c|}{ Independent variables for the board's advisory role } \\
\hline Size of bank & Total assets, in logarithm & ASSETS & positive & positive & 11.400 & 1.427 & 4.378 & 14.222 \\
\hline Age of the bank & $\begin{array}{l}\text { Number of years since the bank was constituted, in } \\
\text { logarithm }\end{array}$ & AGE & positive & positive & 4.205 & 1.197 & 0.000 & 6.280 \\
\hline Leverage & Liabilities-to-total assets ratio & LEVERAGE & positive & positive & 0.927 & 0.049 & 0.052 & 0.981 \\
\hline Activity diversification & $\begin{array}{l}\text { Squared of fraction of operating activity derived } \\
\text { from the loans plus squared of fraction of operating } \\
\text { activity derived from deposits }\end{array}$ & DIVERSIFICATION & positive & positive & 0.482 & 0.056 & 0.000 & 0.500 \\
\hline \multicolumn{9}{|c|}{ Independent variables for the board's monitoring role (substitution effect and monitoring costs } \\
\hline \multicolumn{9}{|c|}{ Substitution effect } \\
\hline $\begin{array}{l}\text { Legal tradition of the } \\
\text { country }\end{array}$ & $\begin{array}{l}\text { Dummy variable that equals } 1 \text { if it is a civil law } \\
\text { country, and zero otherwise }\end{array}$ & CIVIL & positive & positive & 0.382 & 0.486 & 0.000 & 1.000 \\
\hline $\begin{array}{l}\text { Ownership } \\
\text { concentration }\end{array}$ & $\begin{array}{l}\text { Percentage of ownership that is in hands of the } \\
\text { major shareholder }\end{array}$ & OWNERSHIP & negative & negative & 12.840 & 18.533 & 0.000 & 100.000 \\
\hline \multicolumn{9}{|l|}{ Monitoring costs } \\
\hline Growth of the bank & $\begin{array}{l}\text { Book value of total assets minus the book value of } \\
\text { common equity plus the market value of common } \\
\text { equity divided by the book value of total assets }\end{array}$ & Q & negative & negative & 2.844 & 2.386 & 0.000 & 34.780 \\
\hline Risk of the bank & $\begin{array}{l}\text { Return on assets plus equity-to-total assets ratio } \\
\text { divided by the standard deviation of the return on } \\
\text { assets (z-score). Higher z-score indicates lower risk. }\end{array}$ & RISK & negative & negative & 5.369 & 4.348 & -2.742 & 34.578 \\
\hline \multicolumn{9}{|l|}{ Control variables } \\
\hline Return on equity & Returns-to-total equity ratio (\%) & ROE & - & - & 15.015 & 10.467 & -171.373 & 351.532 \\
\hline Merger & $\begin{array}{l}\text { Dummy variable that equals } 1 \text { if there is a bank } \\
\text { merger, and zero otherwise }\end{array}$ & MERGER & -- & - & 0.142 & 0.349 & 0.000 & 1.000 \\
\hline $\begin{array}{l}\text { Code of good } \\
\text { governance }\end{array}$ & $\begin{array}{l}\text { Dummy variable equals } 1 \text { if there is a new code of } \\
\text { good governance in the country of the bank's parent } \\
\text { company, and zero otherwise }\end{array}$ & CODE & - & - & 0.281 & 0.450 & 0.000 & 1.000 \\
\hline
\end{tabular}


Table 2. Models (1) and (2) for the determinants of board size

The table presents our coefficients and standard errors (in parentheses) of the hypotheses' estimations, using generalized method of moments in two-step. BOARD SIZE is the number of total directors; BOARD INDEPENDENCE is the percentage of outsiders; ASSETS is the volume of assets (in logarithm); AGE is the year of bank's creation; LEVERAGE is the liabilities-to-total assets ratio; DIVERSIFICATION is the bank's activity diversification; CIVIL is the dummy variable to identify the legal tradition of the country; OWNERSHIP is the percentage of equity in hands of the major shareholder; Q is the market-to-book value ratio; RISK is the Z-score ratio; ROE is the returns on equity ratio; MERGER is the dummy variable to identify a bank's merger; CODE is the dummy variable to identify a publish date of a code of good governance in the country. The Wald test is a contrast of the null hypothesis of all the coefficients except the constant term. AR2 is a test for the absence of secondorder serial correlation. The Hansen test indicates the validity of the instruments. ***, **, and * indicates a confidence level of above $99 \%$, above $95 \%$ and above $90 \%$, respectively.

\begin{tabular}{|c|c|c|}
\hline Dependent variable & BOARD SIZE & BOARD INDEPENDENCE \\
\hline \multirow[t]{2}{*}{ ASSETS } & $1.344^{*}$ & $0.056^{*}$ \\
\hline & $(0.719)$ & $(0.031)$ \\
\hline \multirow[t]{2}{*}{ AGE } & -0.386 & -0.012 \\
\hline & $(0.914)$ & $(0.017)$ \\
\hline \multirow[t]{2}{*}{ LEVERAGE } & 48.524 & 0.164 \\
\hline & $(45.060)$ & $(1.244)$ \\
\hline \multirow[t]{2}{*}{ DIVERSIFICATION } & -9.050 & 0.153 \\
\hline & $(6.174)$ & $(0.447)$ \\
\hline \multirow[t]{2}{*}{ CIVIL } & -6.357 & $0.181^{* *}$ \\
\hline & $(5.013)$ & $(0.087)$ \\
\hline \multirow[t]{2}{*}{ OWNERSHIP } & -0.034 & -0.001 \\
\hline & $(0.047)$ & $(0.003)$ \\
\hline \multirow[t]{2}{*}{ Q } & 0.004 & $-0.005^{*}$ \\
\hline & $(0.081)$ & $(0.003)$ \\
\hline \multirow[t]{2}{*}{ RISK } & -0.515 & 0.008 \\
\hline & $(0.589)$ & $(0.019)$ \\
\hline \multirow[t]{2}{*}{ ROE } & 0.022 & -0.001 \\
\hline & $(0.061)$ & $(0.004)$ \\
\hline \multirow[t]{2}{*}{ MERGER } & $1.173^{* *}$ & $-0.077^{*}$ \\
\hline & $(0.556)$ & $(0.045)$ \\
\hline \multirow[t]{2}{*}{ CODE } & $-0.778^{* * *}$ & $0.024^{*}$ \\
\hline & $(0.312)$ & $(0.014)$ \\
\hline \multirow[t]{2}{*}{ CONS } & -32.564 & -0.078 \\
\hline & $(38.478)$ & $(1.108)$ \\
\hline YEAR & Included & Included \\
\hline No. obs (groups) & $640(73)$ & $640(73)$ \\
\hline \multirow[t]{2}{*}{ Wald test ( $p$-value) } & 59.78 & 50.89 \\
\hline & $(0.000)$ & $(0.000)$ \\
\hline \multirow[t]{2}{*}{ AR2 } & -0.17 & 1.40 \\
\hline & $(0.862)$ & $(0.163)$ \\
\hline \multirow[t]{2}{*}{ Hansen test } & 30.69 & 34.01 \\
\hline & $(0.631)$ & $(0.467)$ \\
\hline
\end{tabular}


Table 3. Models (1) and (2) including squared and interacted variables

The table presents our coefficients and standard errors (in parentheses) of the hypotheses' estimations, using generalized method of moments in two-step. BOARD SIZE is the number of total directors; BOARD INDEPENDENCE is the percentage of outsiders; ASSETS is the volume of assets (in logarithm); AGE is the year of bank's creation; LEVERAGE is the liabilities-to-total assets ratio; DIVERSIFICATION is the bank's activity diversification; CIVIL is the dummy variable to identify the legal tradition of the country; OWNERSHIP is the percentage of equity in hands of the major shareholder; Q is the market-to-book value ratio; RISK is the Z-score ratio; ROE is the returns on equity ratio; MERGER is the dummy variable to identify a bank's merger; CODE is the dummy variable to identify a publish date of a code of good governance in the country. The $t_{i}$ is the test that contrast the null hypothesis that the sum of the coefficients of the interactive variable (CIVIL*OWNERSHIP; MERGER*OWNERSHIP) and the non-interactive one (OWNERSHIP) is zero. The Wald test is a contrast of the null hypothesis of all the coefficients except the constant term. AR2 is a test for the absence of second-order serial correlation. The Hansen test indicates the validity of the instruments. ***, $* *$, and * indicates a confidence level of above $99 \%$, above $95 \%$ and above $90 \%$, respectively.

\begin{tabular}{|c|c|c|c|c|c|c|}
\hline Dependent variable & & OARD SI & & BOARI & INDEPEI & DENCE \\
\hline ASSETS & $1.814^{* *}$ & 0.571 & $1.005^{*}$ & $0.056^{*}$ & $0.054^{*}$ & $0.040^{*}$ \\
\hline & $(0.886)$ & $(0.914)$ & $(0.593)$ & $(0.031)$ & $(0.032)$ & $(0.022)$ \\
\hline AGE & -0.512 & -0.711 & 0.146 & -0.017 & 0.008 & -0.009 \\
\hline & $(0.662)$ & $(0.665)$ & $(0.638)$ & $(0.017)$ & $(0.025)$ & $(0.021)$ \\
\hline LEVERAGE & 40.875 & 16.940 & 1.111 & 0.880 & 1.060 & 1.285 \\
\hline & (43.044) & $(21.826)$ & (20.646) & (1.251) & $(1.502)$ & (1.359) \\
\hline DIVERSIFICATION & -7.065 & 4.678 & 1.344 & -0.115 & -0.335 & -0.260 \\
\hline & $(7.554)$ & $(6.922)$ & (6.438) & $(0.465)$ & $(0.406)$ & $(0.505)$ \\
\hline CIVIL & -1.605 & - & 0.342 & 0.061 & - & 0.042 \\
\hline & $(4.962)$ & & (1.332) & $(0.065)$ & & (0.069) \\
\hline OWNERSHIP & $-0.306^{* *}$ & $-0.380^{* *}$ & $-0.074^{*}$ & 0.004 & -0.001 & -0.001 \\
\hline & $(0.136)$ & $(0.176)$ & $(0.044)$ & $(0.005)$ & $(0.014)$ & $(0.002)$ \\
\hline SQUARED OWNERSHIP & $0.003^{* *}$ & - & - & 0.001 & - & - \\
\hline CIVIL*OWNERSHIP & - & $0.331^{* *}$ & - & - & -0.001 & - \\
\hline MERGER*OWNERSHIP & - & - & $0.122^{* * *}$ & - & - & $-0.003^{* *}$ \\
\hline & & & $(0.043)$ & & & $(0.001)$ \\
\hline Q & 0.042 & -0.074 & -0.041 & $-0.006^{*}$ & -0.003 & $-0.004^{*}$ \\
\hline & $(0.129)$ & $(0.073)$ & $(0.062)$ & $(0.003)$ & $(0.002)$ & $(0.003)$ \\
\hline RISK & -0.223 & 0.288 & -0.030 & -0.001 & -0.012 & 0.010 \\
\hline & $(0.438)$ & $(0.346)$ & $(0.344)$ & $(0.017)$ & $(0.016)$ & $(0.018)$ \\
\hline ROE & -0.004 & -0.075 & -0.025 & 0.000 & 0.001 & 0.001 \\
\hline & $(0.037)$ & $(0.055)$ & $(0.051)$ & $(0.004)$ & $(0.002)$ & $(0.003)$ \\
\hline MERGER & $1.045^{*}$ & $1.297^{* * * *}$ & - & $-0.084^{*}$ & $-0.030^{*}$ & - \\
\hline & $(0.536)$ & $(0.445)$ & & $(0.051)$ & $(0.018)$ & \\
\hline CODE & $-0.575^{*}$ & -0.244 & $-0.519^{* * *}$ & $0.027^{*}$ & 0.001 & 0.008 \\
\hline & $(0.357)$ & $(0.225)$ & $(0.193)$ & $(0.015)$ & $(0.009)$ & $(0.007)$ \\
\hline CONS & -32.602 & -5.216 & 1.941 & -0.562 & -0.650 & -0.674 \\
\hline & $(0.390)$ & (25.448) & (21.337) & $(1.144)$ & $(1.542)$ & $(1.361)$ \\
\hline YEAR & Included & Included & Included & Included & Included & Included \\
\hline No. obs (groups) & $640(73)$ & $640(73)$ & $640(73)$ & $640(73)$ & 640 (73) & $640(73)$ \\
\hline $\mathrm{t} 1$ & & 4.47 & & & & \\
\hline t2 & & & 6.18 & & & \\
\hline Wald test ( $p$-value) & 56.42 & 89.37 & 71.23 & 80.36 & 35.03 & 106.92 \\
\hline & $(0.000)$ & $(0.000)$ & $(0.000)$ & $(0.000)$ & $(0.028)$ & $(0.000)$ \\
\hline AR2 & -0.40 & -0.39 & -0.81 & 1.61 & 0.98 & 0.87 \\
\hline & $(0.688)$ & $(0.694)$ & $(0.417)$ & $(0.108)$ & $(0.326)$ & $(0.385)$ \\
\hline Hansen test & 36.52 & 48.19 & 48.70 & 30.59 & 31.51 & 31.90 \\
\hline & (0.309) & $(0.271)$ & (0.191) & $(0.588)$ & $(0.857)$ & $(0.845)$ \\
\hline
\end{tabular}

